Scientific Journal Warsaw University of Life Sciences - SGGW

Problems of World Agriculture volume 19 (XXXIV), number 3, 2019: 35-45 DOI: 10.22630/PRS.2019.19.3.44

Maksym Klymenko ${ }^{1}$

National University of Life and Environmental Sciences of Ukraine

\title{
Environmental Taxation as a Policy Instrument for Green Growth
}

\begin{abstract}
The article is devoted to environmental taxation as a tool for green growth and assistant to solve environmental issues of the world and Ukraine in particular. Nowadays, the world's economic growth goes side by side with environmental protection, and taxation aims to become an economic instrument to stop large-scale over-use of energy and consider effective resource utilisation, expand the share of organic farming and move towards "green" economy. The paper identifies the main groups of environmental taxes in the EU countries, analyses the European experience of the economic impact on the environment protection, examines possible ways of environmental taxation reforming in Ukraine, based on successful foreign experience.
\end{abstract}

Key words: environmental taxation, green growth, tax instruments, environmental issues

JEL Classification: E62

\section{Introduction}

We need this planet despite our status, knowledge, and day-to-day concerns. Saving the world is a prerequisite for the existence of everything we know and fight for. Nine out of ten inhabitants of the Earth are breathing in polluted air, which carries a substantial risk to people's health. Microscopic particles can penetrate the respiratory and circulatory system and lead to a disruption of the lungs, heart and brain. Seven million people die prematurely annually from diseases caused by air pollution (including cancer, stroke, heart and lung disease) according to the WHO. Fossil fuel combustion, high emissions in the industry, transport sector and agriculture appear as the central air pollutant.

One of the first historical and critical points of environment preservation was the Paris Agreement (195 states and the EU signed that) (Progress tracker, 2018). Two crucial goals were determined to strengthen the global response to the threat of climate change:

1) prevent the growth of the global average temperature above $2^{\circ} \mathrm{C}$ (if possible - no more than $1.5^{\circ} \mathrm{C}$ ) compared to the preindustrial period;

2) reduction of greenhouse gas emissions into the atmosphere up to zero degrees during the second half of the XXI century.

Each country committed itself to make "nationally defined contributions" to achieve these two goals. Every five years, states should report on contributions made (in 2023 should be the first) and new goals set to the UNFCCC. The system of "naming and shaming" would operate as the Paris Agreement does not impose any sanctions.

Furthermore, in October 2018, the first WHO Global Conference was held in Geneva, where more than 70 countries and organisations committed themselves to improve air quality (Ten threats, 2019). The World Economic Forum, Business Insider, the Global

${ }^{1} \mathrm{PhD}$ student of the NULES of Ukraine, Finance Department; postal address: Heroiv Oborony Str.11, room 515, Kyiv, Ukraine 03041; e-mail: Maxklymenko@nubip.edu.ua; https://orcid.org/0000-0001-6481-9945 
Challenges Foundation (Global Catastrophic Risks, 2018) note the problem of climate change as one of the primary issues on the agenda.

The humankind is on the verge of an ecological catastrophe, and it is necessary to combine the efforts of environmentally oriented countries with the largest polluters to create an efficient way of environment preservation. Although the material below aims to analyse environmental taxation and best practices in the EU countries that can be implemented in Ukraine, further research is needed to investigate instruments conducive for green growth.

\section{Review of the literature}

Theoretical principles of environmental taxation were explored by A. Pigou, N. V. Pakhomova, V. Baumol, A. L. Kashenko. Macroeconomic effects of environmentl taxes with a feasibility of "Win-win" outcomes researched by Jenny E. Eigthart (Ligthart,1998). Moreover, environmental taxation and the green economy are widely discussed nowadays. Herman Vollebergh has reported on environmental taxes and green growth with a stepwise issues analysis of tax instruments as part of the policy on sustainable economic growth. Unbridled economic expansion may pose a serious risk to society in the long term. Offering the right financial incentives through 'environmental pricing' is a key element of policy aimed at sustainable economic growth (Vollebergh, 2012). Lucas Chancel and Simon Ilse discovered the main issues at stake when considering energy-climate tax policies from a social point of view along with options and tools for EU policy makers (Chancel, Ilse, 2014). Lucas Lucien Georgeson, Mark Maslin and Martyn Poessinouw reviewed current shortcomings and made four recommendations to improve measurement for green economy transformations. Proper measurement of the green economy needs to move beyond GDP as the central progress measure and to better track the "transformational green economy" (Georgeson, Maslin \& Poessinouw, 2017). Piciu Gabriela Cornelia and Trica Carmen Lenuta assessed the impact and effectiveness of environmental taxes, considering budgetary criteria (Cornelia, 2012). The financial problems of the green economy were studied by numerous Ukrainian and foreign scientists: I. Varlamova, E. Weizsäcker, I. Bakhovych, O. Gubanova, V. Kravtsov, N. Kraft, S. Mezentsev, R. Klamtam, D. Stiglitz, J. Farley, and others. Also, a broad discussion about environmental tax reform is taking place in the international literature (Fullerton, Leicester and Smith, 2010; De Mooij, Parry and Keen, 2012).

However, even with a large number of publications, further examination required to identify successful foreign experience about adequate functioning of taxation instruments to stimulate citizens and businesses take into account environmental responsibility, which would be an impulse to improve the environmental policy, environmental taxation and an impetus for moving towards an innovative green economy in Ukraine.

\section{Material and methods}

The methodological basis of the study is the theoretical achievements of foreign and domestic scientists, devoted economists to the problems of environmental taxation, report of the European Commission with a pull of data for the EU Member States, OECD database of the environmentally related taxes. However, the research is limited by the period of 2004-2016 years due to the data availability. A complex of general scientific and applied methods of 
studying economic processes was used. In particular, methods of analysis and synthesis, abstraction and concretisation, structural and dynamic comparisons to find the right combination of reasonably designed and relatively easy to implement environmental taxes, assessing the effectiveness of taxes used for environmental regulation, analysing the experience of European countries regarding environmental problems solutions.

\section{Results and discussion}

Nowadays, green growth is a topic of global concern. It aims to foster economic growth and development while ensuring that natural assets continue to provide the resources and environmental services on which our wellbeing relies (Towards Green Growth, 2011). In other words, it takes into account global issues like quality of life and environmental pollution.

Use of taxes as an environmental pricing instrument is not new. They play an essential role in any country's development, even though taxation is not a goal itself. Many economists agree that environmental pricing is essential for a properly functioning market economy aimed at sustainable long-term economic growth (De Mooij, Parry and Keen, 2012). Environmental tax - a tax whose tax base is a physical unit (or a proxy of a physical unit) of something that has a proven, specific negative impact on the environment.

The following criteria to assess environmental taxation are commonly used (Vollebergh, 2012):

1) allocative effectiveness and (dynamic) efficiency. Both consider the correction of market failure and externalities. Market failure (weak or absent markets) is the leading cause of environmental decline, as prices often do not adequately account for the costs of environmental resource use. Green growth needs taxes that put an adequate price on negative externalities (e.g. environmental pollution and traffic congestion) (Fullerton, Leicester and Smith, 2010). Environmental pricing should comprise an intelligent combination of "sticks" (taxes as economic incentives to reduce $\mathrm{CO} 2$ emissions, waste production and water consumption) and "carrots" (subsidies for green innovations);

2) distributive justice. "The polluter pays" is often the guiding principle of environmental pricing. Considered contribution to pollution by individual citizens and businesses, not on their ability to pay, revenue from environmental taxes may be returned to them in the form of lower-income and corporate taxes;

3) feasibility. There is an obvious tension between the objective of tax simplification and the effective use of environmental taxes as an environmental policy instrument. A complex tax structure is difficult to understand for taxpayers and expensive to implement. However, alternative policy instruments for environmental pricing, such as subsidies and emission standards should be carefully considered (Vollebergh and Werf, 2013). 
From the welfare theory point of view (Pigouvian tax), environmental taxes are an effective and efficient instrument to correct adverse external effects on the environment (De Mooij, Parry and Keen, 2012; Fullerton, Leicester and Smith, 2010). If the consumption or production of a given energy product results in emissions and associated environmental damage, this damage should be discounted in its market price, for instance through an environmental tax per unit emission. This environmental tax will drive a wedge between the price that producers receive and the price that consumers pay (market price including taxation). As a result of the higher market price fewer of these polluting products will be sold, which is exactly the objective of the environmental tax (illustrated in Figure 1).

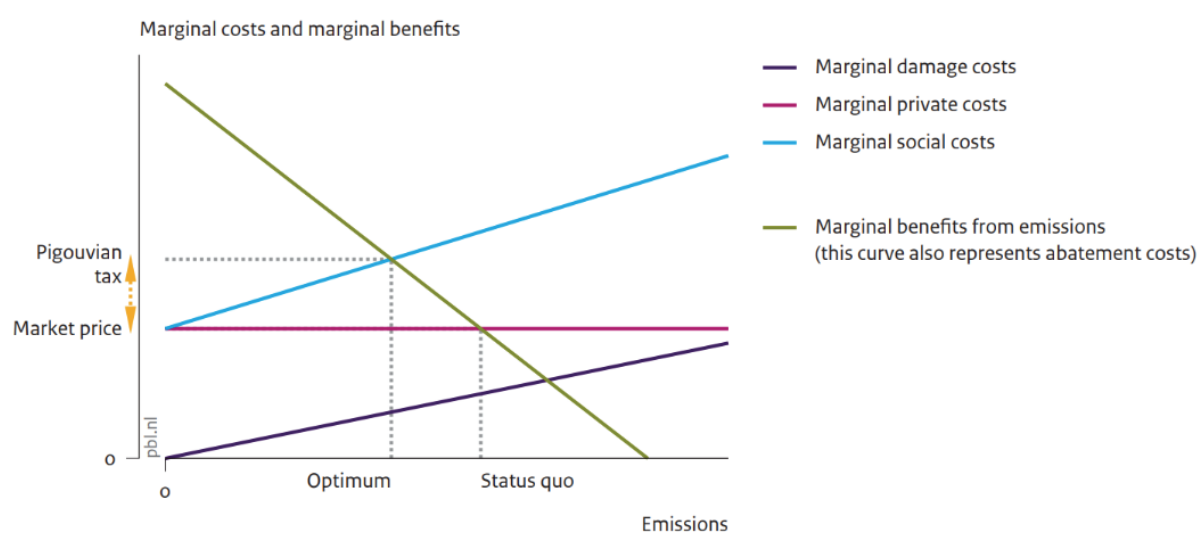

Fig. 1. Optimum production and emissions

Source: Vollebergh, 2012.

Assume that producers (or consumers) cause environmental damage through emissions for every unit of production (or consumption) as shown by the increasing marginal damage costs of emissions. At the same time, the marginal benefits from emissions (or consumption) decrease with the amount of product consumed. The price is usually established at a level where the marginal benefits equal the marginal private production costs. As long as producers (or consumers) maximise their profits (or benefits) without taking account of environmental damage, they will choose a production (or consumption) level that provides the greatest benefit to themselves (status quo in Figure 1). However, from a social perspective, this is not the optimal outcome, because of the high marginal damage costs that should be discounted to achieve the social optimum. The Pigouvian tax imposed, the social optimum is achieved because rational actors (producers or consumers) strive to minimise their payment of pollution taxes through waste reduction or cutting their emissions using the cheapest available abatement technologies or behavioural options, social welfare increases.

Pigovian tax rates often challenging to estimate, and some environmental taxes may include more than the Pigovian taxes as described in economic theory (e.g. the rate of an energy tax may be set with fiscal motives in mind and may be higher than the marginal damage from the production and use of the energy products). In research (Bruvoll, 2009) it is shown that for polluting goods, the tax rate should not only vary according to the social costs but also according to the elasticity of demand. According to the rule of Ramsey (Ramsey, 1927) the tax rate of an optimal fiscal tax is set inversely proportional to the price 
elasticity of demand for the tax base, i.e. the more inelastic the demand, the higher the tax rate. This minimises the so-called 'dead-weight costs' of taxes, i.e. the distortion of economic activities by taxation.

Also, environmental taxes can promote environmental innovation technologies in contrast to other policy instruments. Nontradable quotas force companies to limit their emissions to the optimal level but provide no incentive to invest in improvements beyond this level. This is due to the fact that emissions within the quota are free. In the case of a tradable permit system, the new technology would reduce the market price of emission permits to a level below the optimal tax rate; the incentive for innovation will be weaker over the next trading period. However, government measures that (unintentionally) encourage polluting activities (environmentally harmful subsidies, e.g. tax exemptions, reduced tax rates, tax expenditures or direct subsidies) are at odds with environmental pricing (Towards Green Growth OECD, 2011).

The Center for Energy Development and Environmental Protection Strategy Research, Jiangsu, China analyzed the impact of environmental tax on green development by using a four-dimension dynamical system. The establishment of the system is based on the complex and dynamic interactions among economic development, pollution emissions, resources consumption, and environmental tax, where roles of environmental tax are reflected by the linear parameters.

Results indicate a robust beneficial role of environmental tax on green development. Furthermore, when an environmental tax is imposed, a firm government control, an active consumer awareness, an advanced technology level can stimulate economic growth, decrease pollution intensity, and control the resource intensity (Fan, Li and Yin, 2019).

Air quality remains the leading environmental threat to public health. In 2016 the Institute for Health Metrics and Evaluation estimated that diseases related to airborne pollutants contributed to two-thirds of all life-years lost to environmentally related deaths and disabilities. The Yale University and Columbia University in cooperation with the World Economic Forum reported on global metrics for the environment with its ranking of countries around the world on the level of environmental efficiency (Yale University, 2019). 


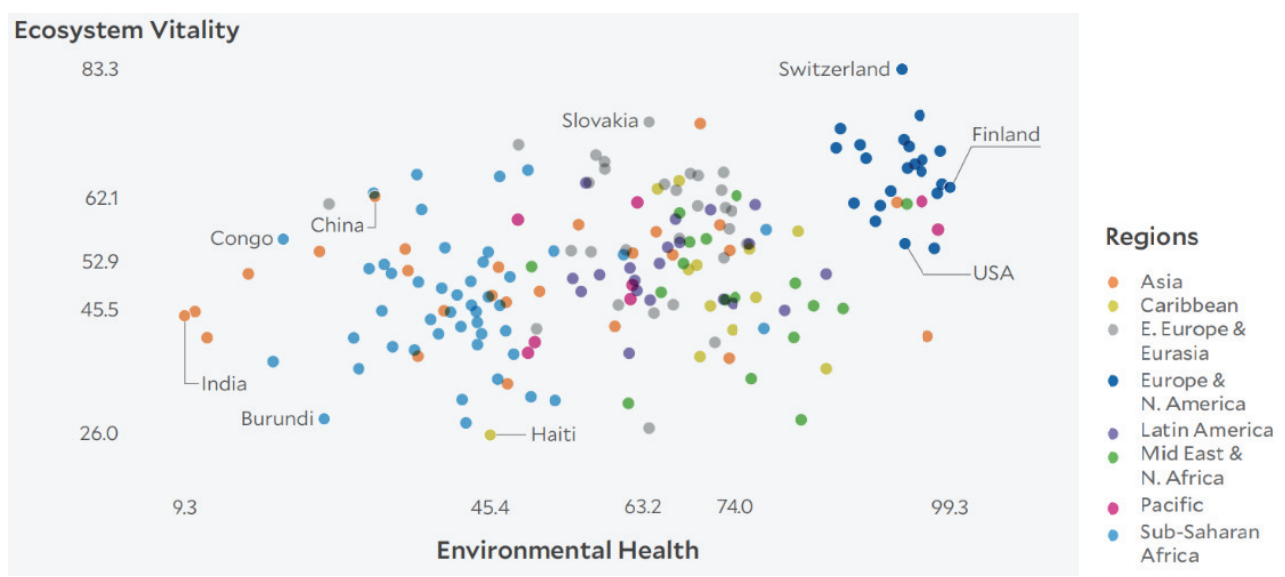

Fig. 2. Two dimensions of environmental performance

Source: Yale University, 2019.

The 2018 Environmental Performance Index (EPI) ranks 180 countries on 24 performance indicators across ten issue categories covering environmental health and ecosystem vitality, that are distinct dimensions of environmental performance - which may be in some tension as economic growth creates resources to invest but adds to pollution burdens and habitat stress (Figure 2).

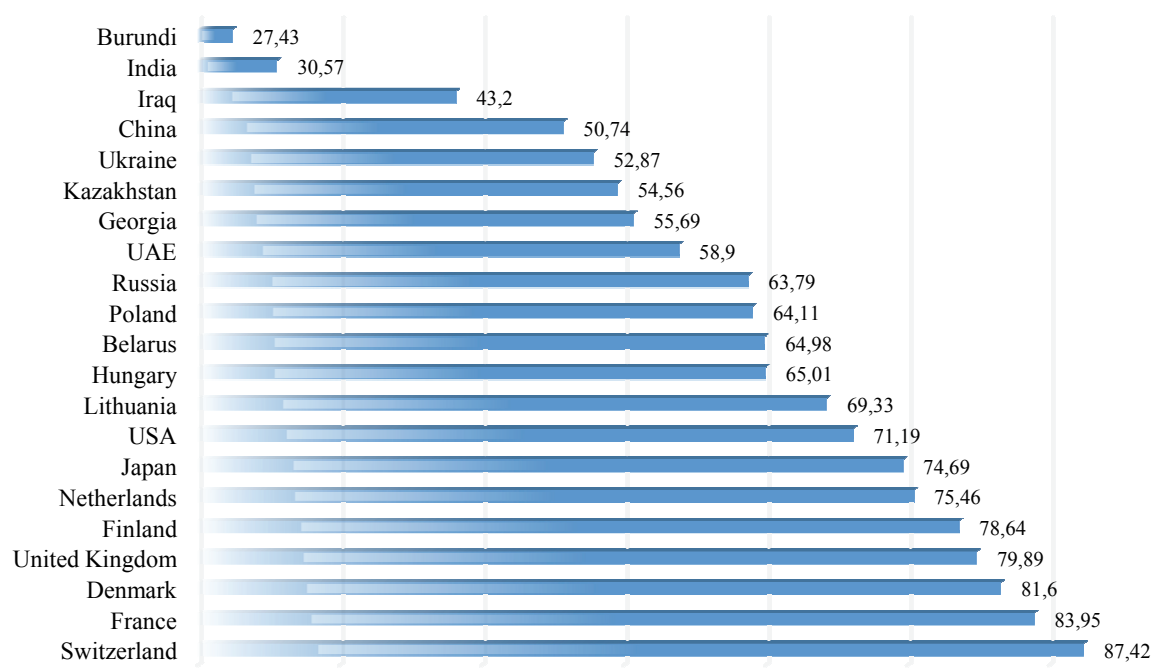

Fig. 3. The rating of Ukraine and other countries of the world, EPI 2018

Source: see figure 2 .

The overall EPI rankings (Figure 3) indicate which countries are doing best against the array of environmental pressures that every nation faces. 
Switzerland leads the world based on strong performance across most issues, especially air quality and climate protection. High scorers exhibit long-standing commitments to protecting public health, preserving natural resources, and decoupling greenhouse gas emissions from economic activity. Among the top 5 leaders also France, Denmark, Malta and Sweden. Ukraine ranked 109th. Nepal, India and Burundi come in near the bottom.

The ecological taxation in Ukraine (TaxLink, 2019) is mainly presented by the environmental tax, that comprises payments on the actual volumes of emissions into the air, discharges pollutants into the water objects, waste placement, the actual amount of radioactive waste temporarily stored, generated and accumulated before April 1, 2009.

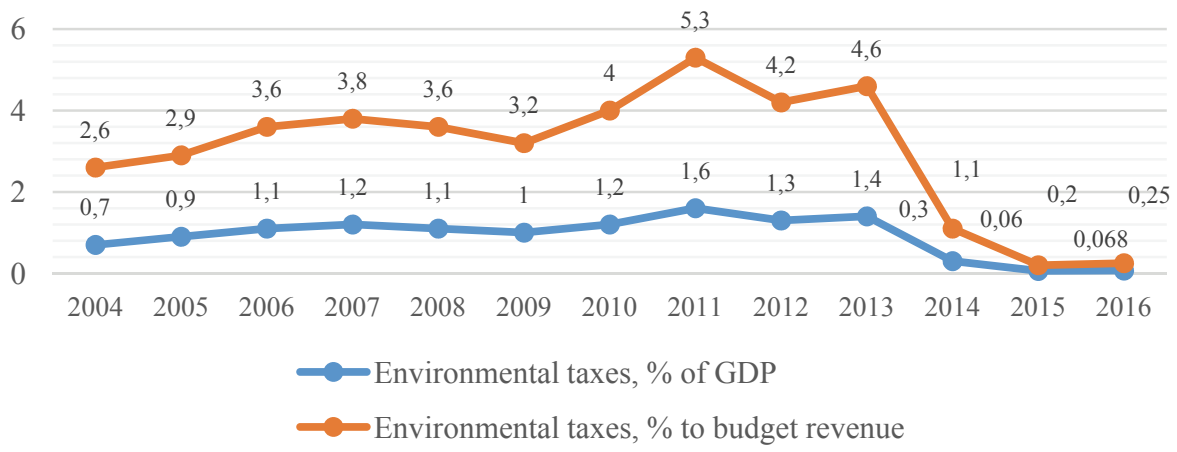

Fig. 4. Share of environmental tax in budget revenues and GDP

Source: State Treasury Service of Ukraine, 2019.

Figure 4 illustrates that the environmental tax is not a budget-making, the share of environmental tax in budget revenues ranged from $0.2 \%$ to $5.3 \%$, in GDP - from $0.06 \%$ to $1.6 \%$. Both indicators were significantly influenced by the economic crisis of 2009 and 2013. The introduction of the Tax Code of Ukraine in 2010 has led to a robust increase in environmental tax revenues because of incrementing tax rates. The reduction of environmental tax revenues in 2014-2017 caused by a decrease of polluters emission by economic agents due to the economic crisis in Ukraine, when many industrial enterprises worked one-two days per week. Another reason was the disappearance from the list of taxation objects environmental taxes on atmospheric air pollution by mobile sources. However, at the same time, in Ukraine, excise tax rates on motor vehicles were raised, increasing budget revenues.

The European Commission distributed environmental taxes by tax bases as follows (Publications Office of the European Union, 2013):

$>$ Energy (Energy products for transport purposes (petrol, diesel, LPG, natural gas, kerosene); Energy products for stationary purposes (fuel oil, natural gas, coal, coke, biofuels, electricity consumption and production, district heat consumption and production, other); Greenhouse gases)

$>$ Transport (motor vehicles import or sale (one off taxes); registration or use of motor vehicles, recurrent (e.g. yearly taxes); road use (e.g. motorway taxes); congestion charges and city tolls; other means of transport (ships, airplanes, railways, etc.); flights and flight tickets; vehicle insurance.

$>$ Pollution (measured or estimated emissions to air; ozone depleting substances; measured or estimated effluents to water; non-point sources of water pollution 
(pesticides, artificial fertilisers, manure); waste management; noise (e.g. aircraft take-off and landings).

$>$ Resources (water abstraction; harvesting of biological resources (e.g. timber, hunted and fished species); extraction of raw materials (e.g. minerals, oil and gas); landscape changes and cutting of trees.

The average tax revenue from environmental taxes in the EU was $2.4 \%$ of GDP or $6.3 \%$ of total tax revenues. After a decline in 2008, their share of GDP increased insignificantly to 2012 due to an increase in energy tax revenues (Fig. 5).

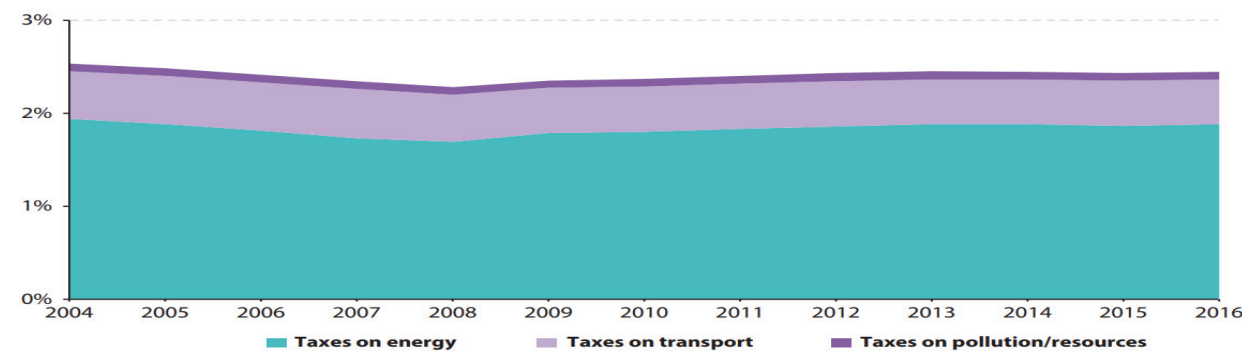

Fig. 5. Average income from environmental taxes EU-28, 2004-2016 (\% of GDP)

Source: Taxation trends, 2018.

The share of revenues in GDP varies between the Member States with the highest share in Denmark (4\%) and Slovenia (3.9\%). Luxembourg, Slovakia, Ireland and Spain have the lowest rates of $1.8 \%$.Fig. 6 . shows that transport and energy taxes are the most widespread in the EU countries. So, energy taxes take near $72 \%$ of the total environmental taxes revenue in the EU and transport only $23 \%$.

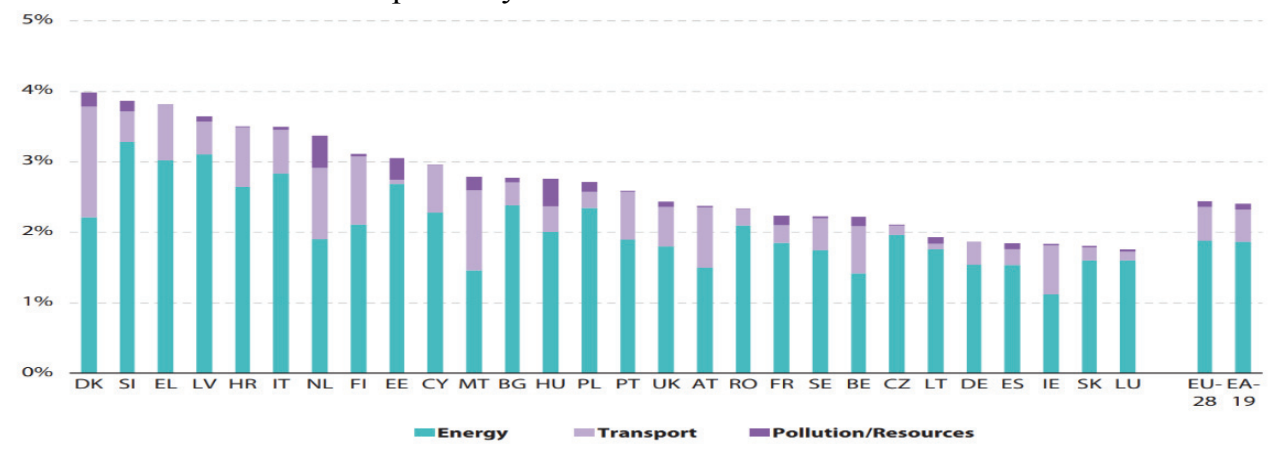

Fig. 6. Structure of Environmental Taxation EU-28, 2016 (\% of GDP) (Taxation trends, 2018) Source: see figure 5 .

About $70 \%$ of energy taxes come from motor fuel tax (Fig. 7). In the six member countries, the fuel tax accounts for about $90 \%$ of energy taxes. Denmark, Italy, the Netherlands, Sweden and Finland have the smallest share of fuel taxes (about 40-60\%). Most in Slovenia, Latvia and Greece (3.3\%, 3.1\% and 3\% of GDP respectively). 


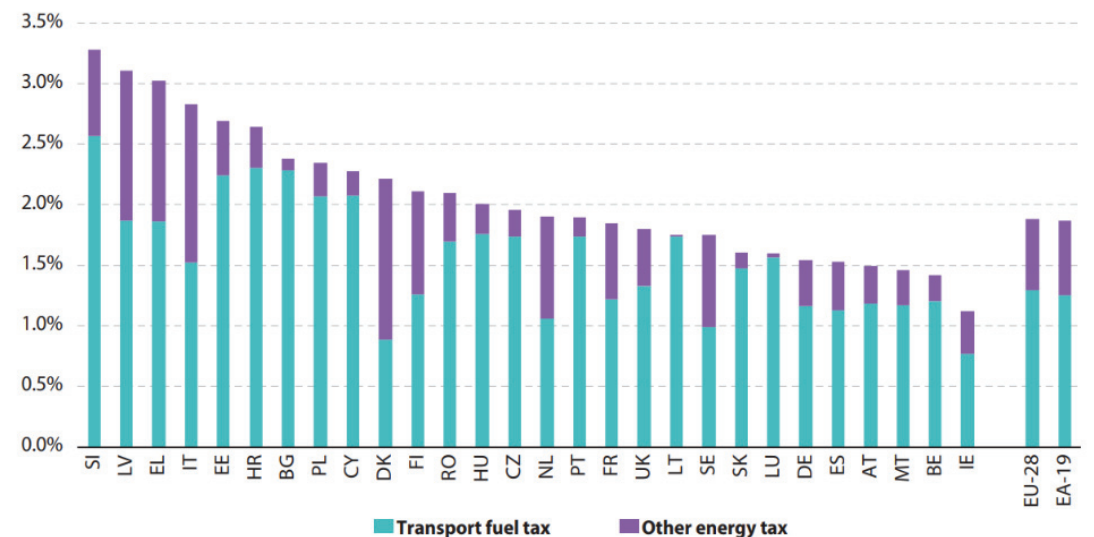

Fig. 7. Revenues of energy taxes EU 28, 2016 (\% of GDP) (Taxation trends, 2018)

Source: see figure 5 .

The new European strategy for economic development "Europe 2020: A strategy for smart, sustainable and comprehensive growth" pays much attention to implementing the idea of more rational use of natural resources, improving the environmental situation, developing new environmentally friendly technologies. According to the only environmental strategy, which is scheduled for 2020 and is called "Strategy $20-20-20$," it is planned to reduce greenhouse gas emissions by $20 \%$ (compared to 1990), reach $20 \%$ of renewable energy, the share of energy production at the expense of renewable sources of energy, and the total energy consumption of member states should be reduced by $20 \%$ (Europe 2020 ).

Therefore, for Ukraine, which is positioning itself as a state, oriented on European values, it will be logical to take into account the experience of "colleagues". For example, in Sweden and the United Kingdom, some environmental taxes are introduced to determine the direct obligation of the state to spend revenues from environmental taxes on reducing PIT and SSCs. Currently, more than 520 types of environmental taxes are widely used in the OECD and EU, which encourage economic operators to reduce pollutant emissions (Towards Green Growth OECD, 2011).

\section{Conclusions}

Looking globally, we have positive shifts toward ecological situation improvement. China abolished construction plans of hundreds of coal stations. India pledged to receive $40 \%$ of its energy from renewable sources by 2020 . Due to the introduction of green energy, $\mathrm{CO}$ emissions have slowed down, but emissions from other greenhouse gases, such as methane, continue to rise.

Ukraine is performing the first steps to harmonise and reform the environmental taxation system. In order to progress, it is necessary to take the experience of the countries which managed to succeed in this field. The recommendations are as follow:

- differentiate environmental tax rates by regions; 


\section{M. Klymenko}

- increase environmental tax rates and control over the return of funds accumulated from environmentally harmful industries in more polluted regions to improve the ecological situation and stimulate business entities to consider environmentally friendly technologies;

- environmental pricing as an instrument in the government's toolbox should be carefully and properly integrated with existing instruments in order to prevent unnecessary welfare losses;

- apply increased progressive tax rates for over limit pollutions;

- apply tax on fertilisers and pesticides;

- reduce the costs of environmental tax administration;

- $\quad$ subsidise businesses and households for CHP and clean energy production (the SDE+ scheme experience of the U.K. and Netherlands). Provide low-interest loans to foster environmentally sound production;

- $\quad$ apply accelerated depreciation, which allows faster updating of fixed assets;

- introduce preferential rates / VAT exemptions for the sale of environmental equipment;

Environmental taxes not only directly address environmental damage but also indirectly influence the direction of technological development. This effect should be taken into account when assessing the importance of taxes for green growth because technology development is also subject to market failures.

\section{References}

Progress Tracker Paris Agreement Work Programme. Access mode: https://unfccc.int/documents/183430.

Ten threats to global health in 2019. World Health Organization. Access mode: https://www.who.int/ru/ emergencies/ten-threats-to-global-health-in-2019.

Global Catastrophic Risks 2018. Access mode: https://api.globalchallenges.org/static/files/GCF-Annual-report2018.pdf.

Vollebergh, H. (2012), Environmental taxes and Green Growth, The Hague: PBL Netherlands Environmental Assessment Agency. Access mode: https://www.pbl.nl/en/publications/environmental-taxes-and-greengrowth.

Georgeson, L., Maslin, M., Poessinouw, M. (2017). The global green economy: a review of concepts, definitions, measurement methodologies and their interactions. Geography and Environment 4(1), doi: 10.1002/geo2.36.

Piciu, G.C., Trică, C.L. (2012). Assessing the Impact and Effectiveness of Environmental Taxes. Procedia Economics and Finance 3, 728-733.

Fullerton, D., Leicester, A., Smith, S. (2010). Environmental taxes, IFS, Report of a Commission on Reforming the Tax System for the 21st Century, London.

De Mooij R.A., Parry, I., Keen, M. (eds.) (2012). Fiscal policy to mitigate climate change, Washington: International Monetary Fund.

Towards Green Growth OECD. (2011). Access mode: https://www.oecd.org/greengrowth/towards-green-growth9789264111318-en.htm.

Fullerton, D., Leicester, A., Smith, S. (2010). Environmental taxes, IFS, Report of a Commission on Reforming the Tax System for the 21 st Century, London.

Vollebergh, H.R.J., Van der Werf, E. (2013). Standards for eco-innovation. Mimeo.

Bruvoll, A. (2009). On the measurement of environmental taxes. Discussion papers 599. Statistics Norway research department.

Ramsey, F. (1927). A contribution to the theory of taxation. Global metrics for the environment: Ranking country performance on high-priority environmental issues. Access mode: https:/epi.envirocenter.yale.edu/ downloads/epi2018policymakerssummaryv01.pdf.

Tax Code of Ukraine. Access mode: https://taxlink.ua/ua/normative_acts/podatkoviy-kodeks-ukraini/.

The State Treasury Service of Ukraine. Access mode: https://www.treasury.gov.ua/en. 
Eurostat Environmental taxes statistical guide. Access mode: https:/ec.europa.eu/eurostat/documents/ 3859598/5936129/KS-GQ-13-005-EN.PDF.

Taxation Trends in the EU. Access mode: https://ec.europa.eu/taxation customs/sites/taxation/files/ taxation_trends_report_2018.pdf.

Europe 2020. A strategy for smart, sustainable and inclusive growth. Communication from the Commission European Commission. Brussels, 2010, 03 March. 32 p.

Impact of environmental tax on green development: A nonlinear dynamic system analysis. Access mode: https://www.ncbi.nlm.nih.gov/pubmed/31483801.

Ligthart, J.E. (1998). The Macroeconomic Effects of Environmental Taxes: A Closer Look at the Feasibility of "Win-Win" Outcomes. Access mode: https://www.cbd.int/financial/fiscalenviron/g-fiscalmacro-imf.pdf.

Chancel, L., Ilse, S. (2014). Environmental taxes and equity concerns: A European perspective. Access mode: http://www.socialplatform.org/wp-content/uploads/2014/01/Environmental-taxes-and-equity-concerns Definitive-Version.pdf.

\section{For citation:}

Klymenko M. (2019). Environmental Taxation as a Policy Instrument for Green Growth. Problems of World Agriculture, 19(3), 35-45; DOI: 10.22630/PRS.2019.19.3.44 